\title{
Money cares. Institutional Entrepreneurship in the Finnish Social Services Sector
}

\author{
Petra Merenheimo ${ }^{1}$
}

\begin{abstract}
In this article, actions within care marketization are conceptualized as institutional entrepreneurship contesting the present practices of care production. Practices of selling and buying care are described, and the underlying power relations in two care marketization models are analyzed: outsourcing and the so called 'second wave', i.e. the customer choice model, in Finland. Drawing from Bourdieu's concepts of cultural, symbolic, social and economic capital, the article highlights the relevance of capital conversions for understanding institutional entrepreneurship. It is argued that the positions and opportunities to gain a more powerful position are not solely field intern conceptions, but can be related to macro level conceptions. Exploiting such opportunities questions the challenging conception of institutional entrepreneurship, itself. Instead, it is suggested that institutional entrepreneurship can also be conceived as legitimate challenging which points that challenging and conforming may not be necessary to be separated.
\end{abstract}

Keywords: Bourdieu, care marketization, institutional entrepreneurship, opportunities.

\section{INTRODUCTION}

Care marketization is described as a neoliberal wave transforming the present care system (Anttonen and Häikiö, 2011; Koskiaho, 2008). In Finland, there is a strong public call for innovative entrepreneurs that would contribute to cost savings within the ageing society and its growing need for caring services (KTM 2005; STM 2008). Entrepreneurs can be perceived as entities fighting the pressure of this cost efficiency through innovating high value care based on care professionalism. On the other hand, entrepreneurs can also be entities innovating new forms of cost efficient care, which means in fact those within the cost pressure itself. Entrepreneurial entities are often perceived as either socially or economically motivated (Tillmar, 2009). Care

1 Petra Merenheimo, Diplom-Kauffrau, University of Lapland, Yliopistonkatu 8, 96300 Rovaniemi, Finland. Tel.:+358 16 341341. E-mail: petra.merenheimo@ulapland.fi. 
professionalism based entrepreneurship, however, mostly gets labelled as socially motivated non-growth self-employment, or as small business, at the most. What is entrepreneurial, at the end, within care marketization? The discussion around care sector innovation-driven entrepreneurship resembles reminds of the theoretical dilemma within institutional entrepreneurship (IE): can an entrepreneur challenge the rules he or she she acts within?

Since the ongoing process of care marketization is often conceived as challenging the present practices of care provision, it offers an interesting context to study IE. Resent research argues that certain field positions offer better opportunities for institutional change, than others. This is because dominating positions imply better resources to induce change, whereas the dominated positions lack resources (Battilana, 2006; Leca, Battilana and Boxenbaum, 2008). However, not all actors are motivated to change the status quo. Newcomers are said to be more likely to challenge the institutional practices, whereas insiders mainly fit in to them (De Clercq and Voronov, 2009a). This is because newcomers are outsiders to the context, whereas especially those insiders who have a dominating position within the context, may have more to lose. Contextual breaks are regarded as a source for innovations and contextual change (Mutch, 2007).

Scholars point out that it is possible for actors to move from one position to another and so gain more power, i.e. 'position-taking', which are acts of differentiation from other field participants (Emibayer and Johnson, 2009). They, therefore, represent challenging actions. Recent research points out that although such challenging acts can be reverted to certain individual actors, institutional change is not accomplished by one actor, only (Powell and Bromley, 2013). Whether an act results in a change within its context, or not, it is, instead, a result of field level negotiations (Lounsbury and Crumley, 2007) and acceptance (De Clercq and Voronov, 2009a). Research on institutional entrepreneurship increasingly acknowledges the interplay between single challenging acts and context, and between opportunities and power. This article argues, however, that the conforming and challenging character of entrepreneurial acts cannot be necessarily distinguished from each other. Instead, it demonstrates how even newcomer challenging acts in fact can be based on legitimate conceptions of the field. Furthermore, these conceptions can be related to wider macro level understandings, which means that whether an act is perceived as challenging or not, it is not an entirely field-intern matter.

In this article, care provision is conceptualised as institutional practices of the Nordic welfare model. Through marketization, these practices are changing. With help of Pierre Bourdieu's (1986) concept of capital, the article studies newcomer actions within this change, that are conceived as 
challenging the Nordic welfare model. It explores positions in the field and relations between them. Conceptualising the field as power relations between positions, enables studying the challenging character of the newcomer entrepreneurial actions. The following chapter introduces recent research on institutional entrepreneurship and then explains the Bourdieusian concept of capital. The context of Finnish care marketization and the methodology is described in the next chapters. The sixth and seventh chapters analyse and discuss the capital forms and their relations in the care sector. The last section concludes the findings and their relevance for institutional entrepreneurship.

\section{LITERATURE REVIEW}

\section{Institutional entrepreneurship}

Mainstream entrepreneurship research conceives entrepreneurship as contributing to change in form of creating something new. Institutional entrepreneurship (IE) scholars trace such actions that pursue a change in their organizational context challenging present practices and the power structure (DeClercq and Voronov, 2009a, 2009b, 2009c) and the introduction of new practices (Lounsbury and Crumley, 2007). The concept of institutional entrepreneurship is traced back to DiMaggio (1988) who defines institutional entrepreneurs as 'actors who mobilize resources to create new institutions or transform the existing ones'. The original conception of institutional entrepreneurship implies deliberate change (Greenwood and Suddaby, 2006). Resent research, however, highlights unintentional actions as well (e.g. Mutch, 2007).

IE scholarship increasingly questions the early belief that homogenizing pressures exert similar influences throughout the field (Powell, 2007). Instead of pointing to isomorphism, they seek to determine the conditions under which entrepreneurs are able to oppose institutional pressure and change existing rules. The focus is on unveiling the conditions that enable change, which Leca et al. (2008) divide into the following field characteristics: crisis (Fligstein, 1997, 2001), acute problems indicating crisis (Phillips et al. 2000; Fligstein and Mara-Drita, 1996), high level of heterogeneity (Seo and Creed, 2002), and low degree of institutionalisation (Maguire, Hardy, and Lawrence, 2004; Lawrence and Phillips, 2004). Other scholars emphasise the social position of the actor in the field, stating that position has an impact on access to relevant resources (e.g. Battilana, 2006). Institutional entrepreneurs appear as change agents, as modern princes contesting hegemony in the field (Levy and Scully, 2007). They are interest-driven, aware and calculative (Greenwood and Suddaby, 2006, p. 28). This heroic conception of 
entrepreneurship has been criticised. For example Czarniawska (2009) calls the institutional entrepreneur an 'oxymoron', pointing to the embeddedness of the entrepreneur in the very structure it aims to change, which as such, is a contradiction. Instead, she notes, entrepreneurs and their characteristics are usually defined post hoc, after an institution has been established. Indeed, embedded agency is a widely acknowledged and puzzling paradox among institutional theorists (Battilana, 2006).

Feldman and Orlikowsky (2011) criticise that many institutional approaches regard institutions such as practices, as static. Leaning on Bourdieu's theory of practice (1972), Lounsbury and Crumley (2007) note that practices are institutions, activities that are fundamentally interpenetrated and shaped by broader cultural frameworks'. They involve a broad array of actors. Munir and Phillips (2005) have argued that institutional entrepreneurs take part in the creation of institutions through development of discourses. In doing so, they draw upon and are influenced by the context in which they operate. Hence, their innovative activities are 'significant only in relation to a number of other social changes taking place' (Munir and Phillips 2005, p. 1682). Furthermore, scholars point that structures are amenable to change at certain times. They point to the role of time (Buhr, 2012) and Zeitgeist in change (Czarniawska, 2009).

Finally, the concept of institutional change, has been discussed by scholars. Leaning on Bourdieu, Golsorkhi et al. (2009) they criticize the conception of radical institutional change. They argue that entrepreneurial activities imposing new rules and stakes may change the structure but not abolish it or its foundation. Hence, institutional change remains mainly limited to changes between the field's dominating and dominated positions. Concerning changes in the domination structure, De Clercq and Voronov (2009a) suggest that only the successful activities of those who enjoy innovative legitimacy lead to change. Their unsuccessful activities, and all the activities of actors without innovative legitimacy, merely reinforce the structure. In turn, Czarniawska and Wolff (1998) have pointed out that entrepreneurial failures can also result in the institutionalisation of new practices. Lounsbury and Crumley (2007) argue more neutrally that only activities with significant variation, as compared with the field's normal variation of activities, can result in change. Moreover, such change can only emerge through field negotiations, after which either the current field is revised or a new field of practice is created. All these approaches argue that the conditions for change are themselves embedded in the structure. According to Lounsbury and Crumley (2007), the process leading to change is therefore 'far beyond the scope of any powerful entrepreneur' (p. 1003). This interplay between agents and structure occurs because, despite their durable character, institutions do change through 
performed actions, although this happens slowly and may not shake the fundamentals. The change may even be unintentional (Chiasson and Saunders, 2005). Since research mainly concentrates on successes that have been identified post hoc, the entrepreneurs involved are just described post hoc as decisive in their efforts (Czarniawska, 2009).

Most approaches on IE avoid studying power (Fligstein, 2008) or consider it to be related implicitly to isomorphism alone (Mohr and Neely, 2009, Lounsbury and Crumley, 2007). Lounsbury and Crumley (2007) argue that many approaches concentrate on studying 'how novel innovations or activities become established as taken-for-granted practices as a result of isomorphic diffusion' (p. 993). Resent research locates power to social positions (see Leca et al. 2008, for an overview). Battilana (2006) for example argues that due to their authority, individuals in higher positions are more likely to be able to conduct organizational changes. On the other hand, it is argued (e.g. Battilana, 2006; Leca et al., 2008), that actors at the margins such as individuals in lower status organizations or social groups are less favoured by the institutional arrangements. They have less to lose, and are, therefore, more likely to act as entrepreneurs challenging the current order. But these potential change agents in the margins are less likely to have the key resources needed for entrepreneurial actions (Battilana, 2006). De Clercq and Voronov, (2009c) also point to the importance of cultural and symbolic capital; knowing the rules and having influence on others, in order to be conceived as an institutional entrepreneur. All in all, there seems to exist a theoretical mix of conforming and challenging that is conceived entrepreneurial. How much questioning is possible, after all, in such a mix?

\section{Bourdieu's concept of capital}

Bourdieu speaks of capital and power as virtual synonyms (e.g. Bourdieu, 2005). Power is related to the position in the field structure, which is in turn dependent on the composition and amount of capital - the 'capital portfolio' (Viale, 2008). Bourdieu (1986) emphasises four different forms of capital: cultural, social, symbolic and economic and thus refuses to downplay all social activities at the economic level. Instead of following an overall economic rationale, all the forms of capital and their valuation are field-specific and mutually convertible, but only in accordance with field-specific rules.

Bourdieu (1986) emphasises that cultural capital is strongly linked to the body. Acquiring cultural capital is an investment that requires time and often takes place through hereditary transmission under social disguised conditions. This makes it difficult to recognize. Even though cultural capital also can exist in an objectified state, it remains closely connected to the embodied state. In turn, cultural capital in an institutionalized form, such as qualifications 
or certificates, presents a relative autonomous state of capital vis-à-vis its bearer, and even makes agents exchangeable (Bourdieu, 1986). Bourdieu (1986) underscores that his concept differs from the economic concept of human capital in the sense of academic ability or academic investment in that it underlines domestic transmission of the capital; investment made by the family prior to any academic investment. Furthermore, capital is always field-specific.

Social capital in Bourdieusian terms is a resource consisting of a network of relationships and the accumulated capital (economic, cultural, social, and symbolic) of those positions to which the agent is connected. It means membership in a group offering recognition (Bourdieu, 1986). Bourdieu's concept of social capital is conceived as a resource in social struggles and therefore differs from concepts underlining more collective and universal values such as the trust to which Robert Putnam refers (Siisiäinen 2000). Networks as mutual recognition equip agents not with the mutual trust of the network, but with a potential for field-specific resources (economic, cultural, symbolic and social) that can be mobilized by agents for their actions. Social capital cannot be mutually accumulated through the sum of interactions, but instead through long-term cultural, symbolic or economic investment by agents (Bourdieu, 1986.)

Bourdieu introduces symbolic capital as a specific form, which can be any of the other three forms. Symbolic capital is 'denied capital, recognized as legitimate and misrecognized as capital' (Bourdieu 1990, p. 118). This means that although rights, duties or gifts may appear to be outside selfinterest and egoistic calculation, they can be accumulated in symbolic forms of capital - honour and prestige - and then converted e.g. into economic profits in market transactions (Bourdieu, 1990). Symbolic capital exists only in a field (among a group) that has the capacity to play the game in question. It accepts the illusion of its value as self-evident and thus misrecognises its arbitrariness (Bourdieu, 1990).

Economic capital in Bourdieu's theory is equivalent to that of economic theory; financial resources. But it is also understood through its relation to other forms of capital. By means of his relational concept of capital, Bourdieu emphasises that the reduction of all capital forms to economic capital (economism) fails to recognise the efficacy of the other capital forms. On the other hand, approaches that reduce all exchanges to communication fail to recognise the 'brutal fact of universal reducibility to economics' (Bourdieu, 1986, p. 54.).

The power attached to agents depends on their possession of capital, which provides them with a competitive advantage (Bourdieu 2005). Capital can therefore be seen as a resource, and, consequently, access to field-specific 
resources are crucial for agency. It is tempting to treat capital forms - like any other object - as static resources. However, Bourdieu himself warns of treating research objects as given and suggests focusing on the relationality between the properties that characterise them (Bourdieu and Wacquant, 1992).

\section{The context of the Finnish care marketization}

Finland applies the Nordic model of the welfare state which is based on the principles of universalism and equality. These refer to the equal access of citizens to social and health care services, regardless of their financial capacity. Equal access is enabled through tax-based financing. So are fees of the elderly residential care adapted according to the individual's financial situation. Tax revenues then compensate the remaining deficit. This principle of distributed responsibility and shared solidarity is the main difference to other welfare models in the EU, such as to the family centred model.

With 'care', this article refers to social services. Social services include child care, elderly care, care of the disabled and intoxicant abusers, as well as home-help services. Nordic social scientists have engaged in a lively discussion of the ongoing change in the Nordic welfare regime and its implications for care workers and clients. Although the Nordic system traditionally relies on public-sector service production, the role of public sector is changing (Anttonen and Häikiö, 2011). Sweden and Finland have been the most active of the Nordic countries in their marketization efforts and have shrunk the role of public sector service production (Anttonen and Häikiö, 2011). However, compared even with Sweden, Finland is a 'latecomer' in the marketization of care and there is little empirical research on the topic (Anttonen and Häikiö, 2011). In this paper, the focus is on the ongoing marketization process in Finland, but since developments in Finland and Sweden are apparently similar, experiences are also used from the latter. Outcomes from Sweden help us to understand the Finnish process and allow to examine it now, as it is unfolding, and not post hoc.

Marketization is a process where public sector services are increasingly produced by the private sector. Marketization can be conceptualised according to the involvement of both competition and private sector actors in service production (Anttonen and Meagher, 2013). In the care sector, marketization in the form of outsourcing is called first-wave marketization (Sundin and Tillmar, 2010). It has existed in both Sweden and Finland for quite some time, but since the 1990s, private sector care provision has grown and continually replaced public-sector care. Outsourcing is the most common way to contract out elder-care services to the private sector, but it is increasingly 
regarded as time-consuming (Erlandsson et al., 2013). The customer choice models that local authorities adopt nowadays can be seen as 'second wave marketization' (Erlandsson et al., 2013). The entrepreneurship perspective is seldom encountered in Nordic care marketization research. The care field represents a case where newcomers to the field, despite public criticism and specific concrete attempts to favour micro entrepreneurs, are successful.

\section{METHOdOLOGY AND DATA}

This paper draws from the most recent research on Nordic, and especially on Finnish care marketization and care sector entrepreneurship, which are used as secondary data. The publications of research project results (Norma Care, 2013, Anttonen et al,. 2009, NordForsk research report, 2013), international articles (Anttonen and Häikiö, 2011, Bourne, 2010, Kovalainen and Österberg, 2000, Kovalainen and Österberg-Högstedt, 2011, Sundin and Tillmar, 2008, Sundin and Tillmar, 2010; Sundin, 2011; Tillmar, 2009; Åkerblad 2009) and other publications (Koskiaho, 2008; Österberg-Högstedt, 2009) offer rich insights into the topic. The article highlights some successful actions of newcomers to the field that are given much attention in this literature. They offer a window to the care sector field. The literature is complemented with government reports on the care sector (KTM, 2005, STM, 2008, TEM, 2010, 2012).

The purpose here is not to describe the field as a whole, nor identify all participants or explain their contributions to care marketization in full detail. Instead, institutional change is tracked as a gradual process and emerging practices are followed even before they are institutionalised. In the literature, researchers report and document moving from the first wave marketization (outsourcing) to the second wave (customer choice). Out of this literature, the analysis begins by identifying the buying and selling practices in the outsourcing model and describes how newcomers challenge them, and then moves towards the customer choice. By means of Bourdieu's concept of capital, some forms of capital are interpreted that seem relevant to the field. Capital enables to grasp the role of power within IE. Bourdieu's concepts are criticised for their fuzziness (DiMaggio, 1979; Mouzelis, 2004). Indeed, it is a risky business to interpret clear-cut concepts out of the complex world. Since it is not the aim here to map the care field as a whole, however, but to develop concepts to understand how challenging the field can take place, and to scrutinise the role of power within it, making some simplifications and drawing examples are justified.

Individual agents sense their opportunities for taking action. But mere acts, arguments, services, products etc., can make opportunities for taking 
action, or position-takings, as Emirbayer and Johnson (2009) call them, visible. The article describes some of these position-takings that in the literature are considered new and threatening the the Nordic welfare model. Their challenging character is then analyzed with the help of the interpreted capital forms and their relations: previous analyses of marketization are read through the Bourdieusian categories. The literature documents how experiences from the outsourcing model have led to the incorporation of some activities into field practices, whereas at the same time a totally new package of practices has been introduced, the so-called customer choice model.

\section{CAPITAL FORMS IN THE OUTSOURCING MODEL}

\section{The value of embodied cultural capital}

In Finland, the public sector buys most of the basic services offered by care providers (Kovalainen and Österberg-Högstedt, 2011). The Finnish outsourcing model is therefore characterised by one buyer and several sellers. The public, third and private sectors all produce services and the public sector takes a positive or reasonable attitude towards private production (Kovalainen and Österberg-Högstedt, 2011). There are several ways to buy public services, ranging from an open procedure, where all interested suppliers may submit a tender to the contracting authority, to a framework agreement. The terms of contract for a given period are agreed upon by the counterparts (Karsio and Anttonen, 2013). Local authorities combine price and quality criteria when they buy care. The quality criteria are merely recommended and not prescribed by the relevant legislation (Karsio and Anttonen, 2013). Instead, local authorities define their own quality criteria. It is argued that outsourcing in the form of competitive tendering contributes to efficiency and effectiveness and combats the public-sector financial crisis (Kovalainen and Österberg-Högstedt, 2000).

An ethical conflict between care professionalism and profit maximising has been observed (Österberg-Högstedt, 2009). Care entrepreneurship is even framed by the question of whether care ethics is in any way compatible with profit maximising (Österberg-Högstedt, 2009). It is conceived as compromising with caring (Åkerblad, 2008). There are numerous different interpretations regarding the Nordic welfare state and its duty to cater to either the needs of the market economy or to those of the citizens (Autto, 2012). Advocates of universalism underscore that care is the right of all citizens irrespective of their class, gender or ethnicity (Kröger et al. 2003, after Anttonen \& Häikiö, 2011, p.16) and discuss adequate methods for 
combating various social problems (Koskiaho, 2008). Anttonen (2009) argues that the need of citizens for more and better care and public financing of such care can be regarded as the point of departure of modern Finnish social policy. Citizens are entitled to care, and society is duty-bound to help them with their problems.

Although there are differences between individual services, official reports document that non-profit care provision and low-profit, smallscale entrepreneurship are the most dominant forms of private sector service provided in Finland (TEM, 2010). This conception of legitimate care provision seems to downplay any economic reason in the form of profits. Szebehely and Meagher (2013) point, however, that the Nordic tax-funded care provision is based on collective resources that shall be used effectively. Österberg-Högstedt (2009) notes that the sector in general has not been encouraged to maximise profit. Non-profit organisations do without profit, as the term suggests. Even the salaries in the caring sector are lower than in many other professions with the same level of requirements (Anttonen and Zechner, 2009). It is argued here that this rests on a very one-sided economic understanding of the care field as a cost for the rest of society. This may sound more radical than it actually is. For quite some time, actually, feminist researchers criticise the exclusion of care of economic production theories and its treatment in fiscal rules (Biesecker and Hofmeister, 2010; Himmelweit and Perrons, 2006; Madörin, 2010; Perrons, 2010). In Finland, as elsewhere, fiscal calculating practices categorise care unilaterally as a cost both in the national gross domestic product (GDP) and municipal budgets. Care produces benefits for other productive sectors, however (Himmelweit and Perrons, 2006). These benefits, as well as the contribution of care to welfare in general, are of course difficult to measure quantitatively, but so are their costs, too (Koskiaho, 2008).

Hence, care as a cost is not an independent field level definition. It is even contested by many field participants. But it is clearly a conception, which makes cost-effectiveness within care production desirable, although cost savings in care cannot be verified. Cost savings are therefore promises, which points to their symbolic character. Contribution to cost savings is a form of symbolic capital. It is a 'credit and a kind of advance' (Bourdieu, 1990, p. 120). It is denied and unrecognised capital in the sense that its selfinterest remains unrecognised; it appears to be objective (Bourdieu, 1990). It is actually arbitrary and depends on the game and belief in it. Care provision should be as cheap as possible. Symbolic capital can thus be interpreted to be constructed around the reputation of a cost-saving and selfless care provider. What is interesting here though, is that this particular capital form is not independent from other fields. 
Several forms of cultural capital in the care field can also be interpreted: care professionalism, a non-profit, service-related social orientation, and the knowledge related to large-scale service production. Although these forms are connected to specific agents in the field, such as care professionalism to female entrepreneurs (Kovalainen and Österberg-Högstedt, 2011; Österberg-Högstedt, 2009), or social orientation to non-profit organisations (Karsio and Anttonen, 2013), positions combining some or all of these forms coexist, for example in large-scale, socially oriented care provision (see large scale non-profit, e.g. Karsio and Anttonen, 2013) and in socially oriented entrepreneurship (see e.g. Sundin and Tillmar, 2008; Tillmar, 2009). It is worth noting that the care professionalism of Finnish entrepreneurs is strongly emphasised in its embodied form; education and work experience is conceived to construct entrepreneurial identity (Kovalainen and ÖsterbergHögstedt, 2011; Österberg-Högstedt, 2009). Care entrepreneurship is strongly based on professionalism (Österberg-Högstedt, 2009) and physical caring duties (Åkerblad, 2008). Since local authorities are the sole buyer of care, social capital from the perspective of entrepreneurs concentrates on good relations with the local authority. Outsourcing is strongly regulated by the local authority, which can determine the price and quality criteria. Relations with customers appear important in cases where customers pay for the services themselves. In the outsourcing model this is mainly restricted to complementary services of minor monetary importance.

The importance of economic capital is relevant for financing investments, for example buildings and special equipment. Starting a nursing home requires large amounts of capital, whereas home help services can be carried out with less investment. The amount of economic capital determines the size of the care unit. However, the role of economic capital is concealed. Non-profit care providers enjoy special conditions for selling care and these have economic reasons and effects. There are special conditions that relate to financial grants by foundations ${ }^{2}$ (Karsio and Anttonen, 2013) and result in the privileging of non-profit care provision by local authorities. Privileging is economically motivated by the low prices enabled by financial grants to nonprofit organisations (Kröger, 2009).

\section{Growing value of economic capital}

Recently, large profit-oriented companies have entered the Finnish care market, questioned the conflict between care professionalism and profit orientation, and won competitive tendering. Especially within elderly care, the price actions of profit-oriented newcomer companies in Finland have forced

$2 \ln 2001$, these special conditions and the rights to foundation grants were abolished. 
third sector companies to follow and lower their prices (Karsio and Anttonen, 2013). In Sweden, there has even been a zero-cost bid by an international profit-oriented care company (Sundin and Tillmar, 2010). Low-price companies are typically newcomers in the care field. Within the care sector, newcomers are not known or trusted to the same extent as field insiders (ÖsterbergHögstedt, 2009). Despite lack of trust, why are they successful? Koskiaho (2008) points to cuts in governmental support to local authorities that reduce their financial resources. At the same time, abolition of foundation grants to non-profit care providers ended the special relationship between them and local authorities. Such regulatory changes within institutional theory are perceived as external 'jolts' that grant access to newcomers and raise awareness of alternative logics (Greenwood and Suddeby, 2006), whereas endogenous change is related to actions by institutional entrepreneurship (DiMaggio, 1988). Undoubtedly, negotiations at the societal level increasingly emphasise cost-savings. Hence, compensating for the lack of a selfless reputation with a promised contribution to cost-savings becomes possible or at least easier. As a result, newcomers gain access to a position that combines profit-orientation with cost efficiency.

Newcomers are outsiders to the field. They, therefore, perform a contextual break, which is seen offering possibilities to do things differently than before (e.g. Mutch 2007). It is highlighted here, however, that what we observe here is a conversion of one form of capital into another (Bourdieu, 1986). In concrete, the case demonstrates how economic capital enables acquiring symbolic capital. Bourdieu (1986) points to the convertibility of capital as the basis for strategies for occupying positions in the field. In the care field, conversion opportunities can be revealed through the buying practices of the local authority. The previous chapter described how non-profit organisations enjoy access to foundation grants that enable them to provide care at low prices. Low prices motivate local authorities to construct special conditions for non-profits and relations with them. Non-profits therefore gain a reputation for cost-effectiveness and earn the trust of local authorities. First, this illustrates how social capital can be legitimately converted into symbolic capital and second, that there is an obvious economic element in this conversion practice. Newcomer activities then show that symbolic capital (concerning a reputation for cost saving), which was earlier accessible only with foundation grants or unpaid labour input of entrepreneurs, can also be converted with the funds of private companies.

Successes achieved with low and zero-cost bids indeed unveil the convertibility of economic capital into other forms within the existing power structure. Especially converting economic capital into symbolic becomes visible and appears shocking. Of course, adequate economic resources are 
needed for such a position-taking act. This makes clear that conversions are restricted possibilities. These conversions are conceptualised as opportunities. It is argued that they emerge within the field practices. Power therefore steers opportunity creation, and their exploitation both by the newcomers and insiders.

The profit-oriented actions of newcomers have come to dominate the Finnish care field - even to the extent that non-profits are now obliged to incorporate their activities. Documents of the Ministry of Employment and Economic Affairs report that large companies buy out small providers and thus contribute to centralisation of the sector (TEM, 2012). Public discussion around poor service quality is lively. At the same time, customer choice practices are being introduced in the field. Both in Finland and Sweden, they are expected to induce quality competition and innovation (Erlandsson et al., 2013; STM, 2008). We will next turn to the second wave marketization practices.

\section{GROWING EXCHANGEABILITY OF CAPITAL IN CUSTOMER CHOICE}

Studying institutional change solely through successful entrepreneurial activities bears the risk of neglecting numerous factors contributing to the process. Delmar (2005) for example, notes that concentrating on successful activities leads to a research bias which neglects failures and makes it impossible to say which factors actually contribute to the success. He suggests studying processes before there are clear, identified outcomes. The customer choice model offers the possibility to explore an ongoing institutional change process. It questions outsourcing practices and induces development that in Finland is perceived as radical. The customer choice model is based on the use of vouchers. In 2007, the Finnish Ministry of Social Affairs and Health appointed a working group to discuss the use of vouchers in developing the care sector. It issued an official memorandum suggesting amendments to the law (STM, 2008). The working group comprises experts in care provision and care organisation and includes representatives of the public sector, localauthorities and the private sector. All in all, vouchers are used to enhance the market orientation of the care sector. They are also used to increase diversity among care providers and to encourage entrepreneurship in the care sector (STM, 2008). The customer choice model rests on the idea of free choice among customers and emphasises competition among producers. These are clear market practices. The buying and selling of care services is coordinated through a listing procedure. Local authorities include care suppliers in a list of voucher providers from which individuals choose a care provider (Anttonen and Häikiö, 2011; Sundin and Tillmar, 2010). Instead of paying directly for the services to the care provider as in the outsourcing model, the local authority gives customers a voucher which they in turn use to pay for the services. The local authority determines the value of the voucher, assesses both the 
quality of the provider's service and the individual's care needs (Anttonen and Häikiö, 2011) and informs customers of approved care providers (Sundin and Tillmar, 2010). The list also compares and evaluates providers, their prices and the quality of their services according to pre-set criteria (STM, 2008). Only providers who meet these criteria are approved. The criteria are not legally binding but are set by each local authority itself. Each service is certified and accredited for the provider organization separately (Sundin and Tillmar, 2010). In the official memorandum, customer choice practices are officially recommended for use in all approved services for two reasons; first, they are said to enhance competition and hence cost efficiency and innovativeness and second, they allow individuals to choose their service providers (STM, 2008). In Finland, the purchase of care services with vouchers is the only form of free choice in social and health services (Karsio and Anttonen, 2013).

When compared with outsourcing, voucher implies some changes in the capital relations. One of the changes concerns the embodied form of care knowledge, which concerns employees alone in the customer choice model. Owner-managers of caring companies are not expected to have embodied care knowledge. Instead, care knowledge in its institutionalised form becomes stronger as a legitimate form of cultural capital. This strengthens its exchangeable character. Care knowledge can be acquired by employing care givers. The educational backgrounds of the business owners and managers may vary. This is something Everett (2002) calls devaluation of a capital form, in this case the care education embodied by entrepreneurs. It illustrates a change between relative positions (Bourdieu, 2005). The position based on embodied care professionalism loses its position of dominance. In addition to this restricted conception of care knowledge, new forms of cultural capital can be interpreted. Separate listings and accreditation for each service emphasise the growing relevance of management and administrative knowledge (Sundin and Tillmar, 2010). Selling practices require totally new areas of expertise such as marketing. These developments are indicative of the changing identity of the Finnish care business owners (ÖsterbergHögstedt, 2009). Devaluation of the embodied form of care knowledge partly explains the observed disappearance of the logics of care in care provision in Sweden (e.g. Sundin and Tillmar, 2010). It is characteristic of the customer choice model that economic capital offers legitimate access especially to cultural capital. It enables position-taking based on economic capital; we observe conversion opportunities between economic and cultural capital.

Even though marketization seems to have attracted private sector care providers, especially to residential care (Karsio and Anttonen, 2013), voucher practices have still not been widely adopted. In Finland, vouchers are mainly used for child care, home help (Anttonen and Häikiö, 2011) and cleaning services (Karsio and Anttonen, 2013). Moreover, experiences 
from Sweden show that despite amendments to the enabling legislation, a voucher continues to be applied mainly in home-help or companion services (Erlandsson et al., 2013). According to Nemlander and Sjöholm (2012), some local authorities plan to adopt vouchers in residential care, the proportion of which can be expected to rise. However, the increase in voucher use for example in Helsinki, the largest local authority in Finland, is expected to be moderate. Since customers are required to pay the difference between the true cost of the care and the value of their voucher, use of the system is expected to remain limited to citizens with sufficient financial resources of their own (e.g. Peiponen, 2009).

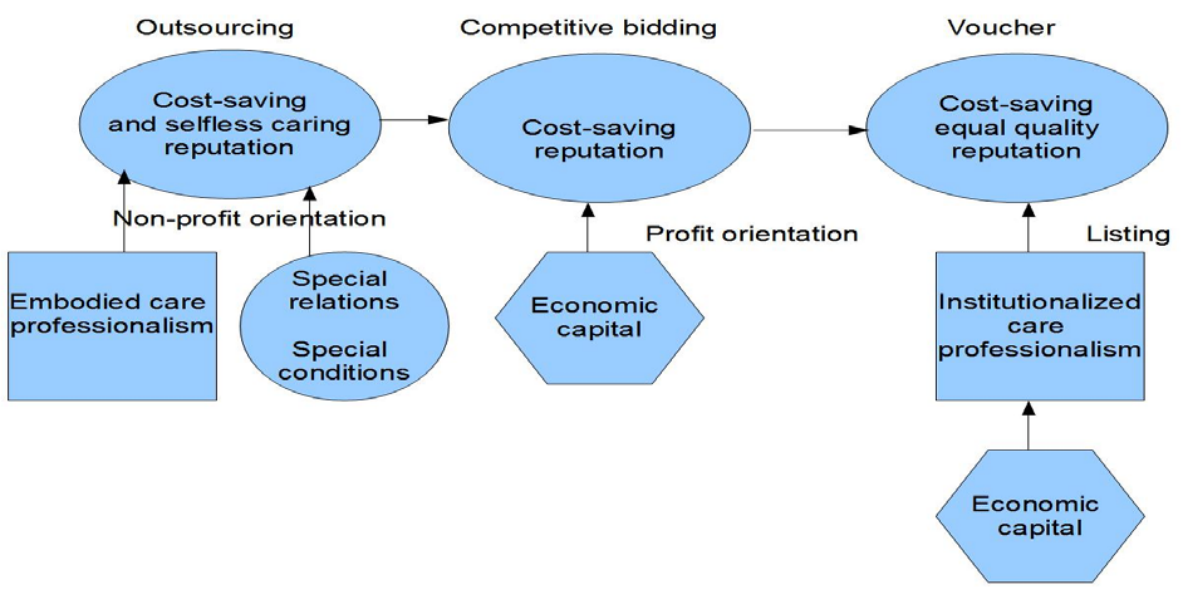

Figure 1. Marketization as a gradual change, illustrated as changes in symbolic, cultural, social and economic capital relations

\section{CONCLUSION}

This article highlights and analyses newcomer actions that contribute to institutional change within the Finnish care sector. This article studies their challenging aspect with the help of Bourdieu's concept of capital. Newcomer actions are approaches to gain a position in the field. The article demonstrates that before newcomer acts took place, dominating positions in the field consisted of certain forms of cultural and symbolic capital which neglected profits. Instead, the newcomer price dumping targets to larger market shares and so questions the non-profit character of the care production practices. New profit-oriented actors access the field, and price dumping gets increasingly practised. Newcomer actions therefore qualify as a form of institutional entrepreneurship. It is argued here, however, that price dumping actually 
exposes how a better position, or a position in the first place, can be acquired through legitimate conversion of a resource into another. This is because even though the non-profit orientation throughout the care production seems to downplay monetary values, it is in fact related to cost effectiveness. Price limit was namely practised in the field already before the newcomers. The public foundation grants for non-profit producers lowered the price level and so the tax-based public spending on care on the community level. There is indeed a recognised monetary motivation for the community to buy non-profit care, since care is categorised as a cost at the municipality budgeting, as it is in the calculation of national GDP, as well. This suggests symbolic capital is not solely a field intern construction, but can be related to macro conceptions, as well. Macro level conceptions should therefore not be considered as an external jolt, but as a practice (of calculation, speech) that relates micro and macro levels.

Now, a reputation as a cost effective care provider can be acquired with profit orientation and economic capital. Within the customer choice, care professionalism will be acquired through hiring care professional work force. Both are examples that demonstrate how exploiting an opportunity and gaining a better position require certain forms of capital, and is therefore restricted to certain positions, only. Obviously, a position with economic capital is in these examples explicitly acknowledged as such. Contextual break simply means newcomers have divergent capital portfolio from the field insiders, in this case above all: money. This means first, that newcomers do not necessarily need large amounts of field specific abilities acquired during a long period of time. Acquiring cultural capital in order to fit in (De Clercq and Voronov, 2009a) is possible through conversion opportunities. Newcomers can gain a powerful position through the conversion of one to another form of capital, an act which fits into the field. Second, this points that newcomers' acts which are perceived as challenging and inducing institutional change, may in fact represent acts of legitimate challenging, a challenging along the power relations. This is when the newcomer portfolio fits with the field, i.e. offers conversion opportunities. Conversion opportunities are relevant for the theory of institutional entrepreneurship. So, how much fitting in is allowed, how much standing out is required for a newcomer, in order to be qualified as entrepreneurial and inducing institutional change? This article argues that the two cannot be necessarily separated. Newcomers who introduce the challenging action of profit-oriented price dumping, can in fact exploit opportunities for legitimate position-takings.

Institutional change is argued to be about transforming the field structure (e.g. De Clercq and Voronov, 2009a). Within the field level negotiations, acts that radically differ from the present practices have the best chances to result in a change (Lounsbury and Crumley, 2007). Based on the evidence from the care field it is noted here that the definition of the 'field' should receive particular notice, and take into account the relations to other fields and macro level conceptions. It is pointed here to the macro level conceptions 
and their role on what is conceived as radical within the field. Neglecting the macro conception of care makes increasing cost effectiveness indeed look like radical transformation of the care field. But whether price dumping is a radical act depends on its relation to the field as whole (Munir and Phillips, 2005). Acknowledging the enduring societal practice to treat care as a cost, makes the emerging practice of price dumping appear just as a reconfiguration of the field. The zeitgeist and time do affect the process (Buhr, 2012; Czarniawska, 2009), but it does not necessarily affect a change but can create 'reworkings' and 'new arrangements' of care, to put it in Adkins' (2004) words. In the care sector these seem to redefine the field as a re-productive sector and to continue keeping it separate from the productive economy. Research on IE already acknowledges field intern relations between individuals and organisations (Battilana, 2006). Future research on IE could move towards designing a relational analysis which also takes into account relations between sectors, and the relations to macro level conceptions. This would have practical consequences on the care sector, as well. It would make visible its contributions to other sectors.

\section{Acknowledgements}

I gratefully acknowledge the support and generosity of Jenny and Antti Wihuri Foundation.

\section{References}

Adkins, L. (2004). Freedom or habit of gender? The Sociological Review, 52(2), 191-210.Åkerblad, L. (2009). Hoivayrittäjän arki: lämpöä, puhtautta ja johtamista. Janus 17(4), 313-328.

Anttonen, A. (2009). Hoivan yhteiskunnallistuminen ja politisoituminen. In: A. Anttonen, H. Valokivi, M. Zechner (Eds.), Hoiva, tutkimus, politiikka ja arki (pp. 54-98). Tampere: Vastapaino.

Anttonen, A. \& Häikiö, L. (2011). Care 'going market': Finnish elderly-care policies in transition'. Nordic Journal of Social Research, 1-21.

Anttonen A. \& Meagher G. (2013). Mapping marketization: concepts and goals. In: G. Meagher, M. Szebehely (Eds.), Marketization in Nordic eldercare a research report on legislation, oversight, extent and consequences (pp. 13-21). Stockholm: Stockholm University.

Autto, J. (2012). Päivähoitopolitiikka kamppailuna hyvinvointivaltiosta. (PhD dissertation). Rovaniemi: University of Lapland.

Battilana, J. (2006). Agency and institutions: The enabling role of individual's social position. Organization 13(5), 653-676.

Biesecker, A. \& Hofmeister, S. (2010). Im Fokus: Das Re(Produktive). Die Neubestimmung des Ökonomischen mithilfe der Kategorie $\operatorname{Re}($ Produktivität). In: C. Bauhardt, G. Caglar (eds.), Gender and Economics (pp. 51-80). Wiesbaden: VS Verlag. 
Bourdieu, P. (1972). Outline of a theory of practice. Cambridge: Cambridge University Press.

Bourdieu, P. (1986). The forms of capital. In: Richardsson, JE (Ed.), Handbook of theory of research for the sociology of education (pp. 241-258). New York: Greenword Press.

Bourdieu, P. (2002). Social space and symbolic power. In: Haugaard, M (Ed.), Power: A reader (pp. 14-25). Manchester: Manchester University Press.

Brush, C., de Bruin., A. \& Welter, F. (2009). A gender aware framework for women's entrepreneurship. International Journal of Gender and Entrepreneurship, 1(1), 8-24.

Buhr, K. (2012). The inclusion of aviation in the EU emissions trading scheme: Temporal conditions for institutional entrepreneurship. Organization Studies, 33(11), 1565-1587.

Chiasson, M. \& Saunders, C. (2005). Reconciling diverse approaches to opportunity research using the structuration theory. Journal of Business Venturing, 20, 747-767.

Czarniawska, B. (2009). Emerging institutions: Pyramids or anthills? Organization Studies, 30(4), 423-441.

Czarniawska, B. \& Wolff, W. (1998). Constructing new identities in established organization fields: Young universities in old Europe. International Studies of Management and Organization, 28(3), 32-56.

De Clerq, D. \& Voronov, M. (2009a). Toward a practice perspective of entrepreneurship, entrepreneurial legitimacy as habitus. International Small Business Journal, 27, 395-419.

De Clerq, D., \& Voronov, M. (2009b). The role of domination in newcomers' legitimation as entrepreneurs. Organization, 16(6), 799-827.

De Clerq, D. \& Voronov, M. (2009c). The role of cultural and symbolic capital in entrepreneurs' ability to meet expectations about conformity and innovation. Journal of Small Business Management, 47(3), 398-420.

Delmar F. (2005). The entrepreneurial process: emergence and evolution of new firms in the knowledge-intensive economy. In: A. Fayolle, P. Kyrö \& J. Ulijin (Eds.), Entrepreneurship research in Europe, outcomes and perspectives (pp. 55-79). Cheltenham: Edgar Elgar Publishing.

DiMaggio, P. (1988). Interest and agency in institutional theory. In: L. Zucker (ed.), Institutional patterns and organizations: Culture and environment (pp. 3-21). Cambridge Mass.: Ballinger Publishing.

DiMaggio, P. (1979). Review essay: On Pierre Bourdieu. American Journal of Sociology 6, 1460-1474.

Emirbayer, M. \& Johnson, V. (2008). Bourdieu and organizational analysis. Theory and Society, 37, 1-44.

Erlandsson, S., Storm, P., Stranz, A., Szebehely, M. \& Trydegård, G-B (2013). 'Marketising trends in Swedish eldercare: competition, choice and calls for stricter regulation'. In: G. Meagher, M. Szebehely (eds.), Marketization in Nordic eldercare - a research report on legislation, oversight, extent and consequences (pp. 23-75). Stockholm: Stockholm University. 
Feldman, M. \& Orlikowski, W. (2011). Theorizing practice and practicing theory. Organizational Science, 22(5), 1240-1253.

Fligstein, N. (1997). Social skill and institutional theory, American Behavioral Scientist. 40(4), 397-405.

Fligstein, N. (2001). Social skills and the theory of fields. Sociological Theory, $19(2), 105-125$.

Fligstein, N. (2008). Fields, power, and social skill: A critical analysis of the new institutionalisms, International Public Management Review, 9(1), 227-253.

Fligstein, N. \& Mara-Drita, I. (1996). How to make a market: Reflections on the attempt to create a single market in the European Union. American Journal of Sociology, 102(1), 1-33.

Greenwood, R. \& Suddaby, R. (2006). Institutional entrepreneurship in mature fields: the big five accounting firms. Academy of Management Journal, 49(1), 27-48.

Himmelweit, S. \& Perrons, D. (2006). Gender and fiscal rules: How can we afford the rising cost of care? Retrieved from http://www.levyinstitute. org/pubs/CP/May2006_symposium_papers/paper_Himmelweit_ Perrons.pdf

Karsio, O. \& Anttonen, A. (2013). Marketization of eldercare in Finland: legal frames, outsourcing practices and the rapid growth of for-profit services. In: G. Meagher, M. Szebehely (Eds.), Marketization in Nordic eldercare a research report on legislation, oversight, extent and consequences (pp. 85-126). Stockholm: Stockholm University.

Koskiaho, B. (2008). Hyvinvointipalvelujen tavaratalossa. Tampere: Vastapaino.

Kovalainen, A. \& Österberg-Högstedt, J. (2000). Sosiaalinen pääoma, luottamus ja julkisen sektorin restrukturaatio. In: K. Ilmonen (Ed.), Sosiaalinen pääoma ja luottamus (pp. 69-92). Jyväskylä: SoPhi University of Jyväskylä.

Kovalainen, A. \& Österberg-Högstedt, J. (2011). Entrepreneurship within social and health care - a question of identity, gender and profession. Paper presented at the International Council for Small Business (ICSB), Stockholm, Sweden.

KTM Ministry for Economic Affairs and Trade, (2005). Naisyrittäjyys (Female entrepreneurship) publication 11/2005. Retrieved from http://www. yrittajanaiset.fi/doc/Naisyrittajyysjulkaisu_2005.pdf

Lawrence, T. \& Phillips N. (2004). From Moby Dick to Free Willy: Macro-cultural discourse and institutional entrepreneurship in emerging institutional fields. Organization, 11(5), 689-711.

Leca, B., Battilana, J. \& Boxenbaum, E. (2008). Agency and institutions: A review of institutional entrepreneurship. Harvard Working Paper 08096. Retrieved from http://egateg.usaidallnet.gov/sites/default/files/ Review\%20of\%20Institutional\%20Entrepreneurship.pdf 
Madörin, M. (2010). Care Ökonomie - eine Herausforderung für die Wirtschaftswissenschaften. In: C. Bauhardt, G. Caglar, (Eds.), Gender and Economics (pp. 81-104). Wiesbaden: VS Verlag.

Maguire, S. \& Hardy, C. (2009). Discourse and deinstitutionalization: The decline of DDT. Academy of Management Journal, 52(1), 148 - 178.

Maguire, S., Hardy, C. \& Lawrence, T. (2004). Institutional entrepreneurship in emerging fields: HIV/AIDS treatment advocacy in Canada. Academy of Management Journal, 47(5), 657-679.

Mohr, J. \& Neely, B. (2009). Modeling Foucault: Dualities of power in institutional fields. Volume Research in the Sociology of Organizations, 27, $203-255$.

Mouzelis, N. (1989). Restructuring structuration theory. Sociological Review, 37(4), 613-635.

Munir, K. \& Phillips, N. (2005). The birth of the Kodak moment: Institutional entrepreneurship and the adoption of new technologies. Organization Studies, 26(11), 1665-1687.

Mutch, A. (2007). Reflexivity and the institutional entrepreneur: A historical exploration. Organization Studies, 28(07), 1123-1140.

Österberg-Högstedt, J. (2009). Yrittäjänä ammatissaan sosiaali- ja terveysalalla-yrittäjyyden muotoutuminen kuntatoimijoiden ja yrittäjien näkökulmasta. PhD dissertation, Turku: Turku School of Economics.

Perrons, D. (2010). Gender, work and 'market' values. Renewal 18(1-2), 3442.

Phillips, N., Lawrence, T. \& Hardy, C. (2000). Inter-organizational collaboration and the dynamics of institutional fields. Journal of Management Studies, 37(1), 23-44.

Powell, W. (2007). The new institutionalism, The international encyclopedia of organization studies. Sage Publishers. (preprint:

http://www.stanford.edu/group/song/papers/NewInstitutionalism.pdf)

Scott, W (2001). Institutions and organizations. Newbury Park, CA: Sage Publications.

Seo, M. \& Creed, D. (2002). Institutional contradictions, praxis and institutional change: A dialectical perspective. Academy of Management Review, $27(2), 222-247$.

Siisiäinen, M. (2000). Two concepts of social capital: Bourdieu vs. Putnam. Paper presented in ISTR Fourth International Conference "The Third Sector: For What and for Whom?" Trinity College, Dublin, Ireland July 5-8, 2000.

STM Ministry of social affairs and health (2008). Palvelusetelin käyttöalan laajentaminen. Palvelusetelityöryhmän muistio. Helsinki: Sosiaali- ja terveysministeriön selvityksiä 2008:32.

Sundin, E. \& Tillmar, M. (2008). A nurse and a civil servant changing institutions: entrepreneurial processes in different public sector organizations, Scandinavian Journal of Management, 24, 113-124. 
Sundin, E. \& Tillmar, M. (2010). Masculinisation of the public sector Locallevel studies of public sector outsourcing in elder care. International Journal of Gender and Entrepreneurship, 2(1), 49-67.

Sundin, E. (2011). Entrepreneurship and social and community care. Journal of Enterprising Communities, 5(3), 212-222.

Szebehely, M. \& Meagher G. (2013). Four Nordic countries - four responses to the international trend of marketization. In G. Meagher, M. Szebehely (Eds.), Marketization in Nordic eldercare-a research report on legislation, oversight, extent and consequences (pp. 241-284). Stockholm: Stockholm University.

TEM Ministry of Employment and Economy (2012). Sosiaalipalvelut. TEM toimialaraportit, 5/2012. Retrieved from http://www.temtoimialapalvelu. fi/files/1638/Sosiaalipalvelut2012_web.pdf

TEM Ministry of Employment and Economy (2010). Sosiaalipalvelut. TEM toimialaraportit, 11/2010. Retrieved from http://www.ely-keskus. $\mathrm{fi} / \mathrm{fi} /$ tiedotepalvelu/2010/Documents/Etel\%C3\%A4Savon\%20ELY/ Sosiaalipalvelut_2010web.pdf

Tillmar, M. (2009). Societal entrepreneurs in the health sector: crossing the frontiers. Social Enterprise Journal, 5(3), 282-298.

Welter, F. (2011). Contextualizing entrepreneurship - Conceptual challenges and ways forward. Entrepreneurship Theory and Practice, 35(1), 165-184.

Viale, T. (2008). Unpacking the "institutional portfolio", Theoretical elements for an analysis of institutional change through objectification of resources and habitus. Organization and Human Resources Department. HEC School of Management, Paris, France. Retrieved from www.hec. $\mathrm{fr} / . . . / 5035 / . . . / C R \_906 \_$ThierryViale.pdf

\section{Abstrakt (in Polish)}

$W$ tym artykule, działania $w$ ramach urynkowienia opieki sq rozumiane jako przedsiębiorczość instytucjonalna, która podważa obecne praktyki w ramach zapewniania usług opiekuńczych. Opisane sq tu rozwiqzania w zakresie sprzedaży i zakupu opieki, oraz poddany analizie został podstawowy układ sił w dwóch modelach urynkowienia opieki: outsourcing i tzw. "druga fala", czyli model wyboru konsumenta, występujqcy w Finlandii. Czerpiq̨ z koncepcji Bourdieu dotyczq̨cych kapitału kulturowego, symbolicznego, społecznego i gospodarczego niniejsza praca podkreśla znaczenie konwersji kapitału, w celu zrozumienia przedsiębiorczości instytucjonalnej. Twierdzi się, że pozycje i szanse osiqgnięcia silniejszej pozycji nie sq wyłqcznie domenq koncepcji wewnętrznych, ale mogq być zwiqzane z koncepcjami na poziomie ogólnym. Wykorzystanie takich możliwości kwestionuje samq, stanowiqqą wyzwanie, koncepcję przedsiębiorczości instytucjonalnej. W zamian, sugeruje się, że przedsiębiorczość instytucjonalna może być również postrzegana jako uzasadnione wyzwanie co wskazuje, że "trudność" $i$ „zgodność" niekoniecznie muszq być rozdzielone.

Słowa kluczowe: Bourdieu, urynkowienie opieki, przedsiębiorczość instytucjonalna, możliwości. 


\section{Biographical note}

Petra Merenheimo studied business administration at the Goethe University in Frankfurt am Main, Germany. She has worked within female entrepreneurship in Germany and Finland, and currently writes her PhD thesis on entrepreneurship within the care services sector, the University of Lapland, Finland. 